\title{
OCCURRENCE OF CAMPYLOBACTER SPECIES IN HEALTHY WELL-NOURISHED AND MALNOURISHED CHILDREN
}

\author{
Heriberto Fernández*; Fernando Vera; María Paz Villanueva; Andrea García \\ Institute of Clinical Microbiology, Universidad Austral de Chile, Valdivia, Chile
}

Submitted: September 16, 2007; Returned to authors for corrections: October 31, 2007; Approved: November 16, 2007.

\section{SHORT COMMUNICATION}

\begin{abstract}
The occurrence of Campylobacter species in healthy, well-nourished and healthy, malnourished children of low socioeconomic level in Southern Chile was determined. Campylobacter carriers were significantly most frequent among malnourished (31.4\%) than among well-nourished (9.9\%) children. Six species were isolated from malnourished children whereas four were found among well-nourished children. C. upsaliensis was the most frequent (13.3\%) species isolated from malnourished children, followed by $C$. lari (7.6\%) and C. fetus ssp. fetus $(1.9 \%)$.
\end{abstract}

Key words: Campylobacter species, malnourished children, well-nourished children, healthy carriers.

The genus Campylobacter now comprises 20 species and subspecies (19), with C. jejuni subsp. jejuni as the species most frequently isolated from cases of gastroenteritis followed by $C$. coli $(5,16)$. More recently, other Campylobacter species have been recognized as gastrointestinal pathogens in both industrialized and developing countries $(8,11)$. In developing countries, the isolation of Campylobacter from children without diarrhoea is well-documented and it is probably related to poor environmental sanitary conditions and close contact with animals $(2,5,15)$. Among children with diarrhoea, the isolation rates of Campylobacter is higher among malnourished than well-nourished children $(10,14)$, and a strong correlation exists between malnutrition, diarrhoeal illness and poor sanitary conditions $(13,18)$. However, there is little information about the diversity of Campylobacter species that can be carried by clinically healthy, malnourished children (3). The aim of this study was to determine the occurrence of Campylobacter species in healthy, well-nourished and healthy, malnourished children of low socioeconomic level in Southern Chile.

A total of 216 stool samples were obtained by rectal swab from 111 well-nourished and 105 malnourished children under five years of age. Each sample was suspended in $2 \mathrm{~mL}$ nutrient broth $\mathrm{N}^{\circ} 2$ (Oxoid) and $0.1 \mathrm{~mL}$ was plated on modified Skirrow agar plates (6) for the isolation of thermotolerant Campylobacter species. For non-thermotolerant and less frequently isolated species, the passive membrane filter method proposed by Le Roux and Lastovica (13) was used. Briefly, a $0.45 \mu \mathrm{m}$ membrane filter (Millipore) was placed on a sheep blood agar plate without antimicrobials and $0.2 \mathrm{~mL}$ of the fecal suspension was placed onto the membrane filter. After $30 \mathrm{~min}$, another $0.2 \mathrm{~mL}$ was added onto the membrane and the filter was removed from the plate 30 min later. The modified Skirrow agar plates were incubated at $42^{\circ} \mathrm{C}$ for $48 \mathrm{~h}$. The sheep blood agar plates were incubated at $37^{\circ} \mathrm{C}$ for up to five days, both under $\mathrm{H}_{2}$-enriched microaerophilic atmosphere. Phenotypic identification of the species was made by their morphological characteristics, susceptibility to cephalothin and nalidixic acid, growth at 26,37 or $42^{\circ} \mathrm{C}$ and their biochemical profiles using the API Campy system (bioMérieux).

As shown in Table 1, Campylobacter carriers were significantly most frequent among malnourished (31.4\%) than among well-nourished $(9.9 \%)$ children. The number of Campylobacter species isolated from malnourished children was also higher: six species were isolated from this group whereas four where found among well-nourished children. $C$.

*Corresponding Author. Mailing address: Universidad Austral de Chile. Instituto de Microbiología Clínica. Edificio de Ciencias Biomédicas. Campus Isla Teja. Valdivia. Chile, Tel.: 5663 214377. E-mail: hfernand@uach.cl 
Table 1. Campylobacter species isolated from healthy well-nourished and malnourished children of low socioeconomic level

\begin{tabular}{|c|c|c|c|c|c|c|c|c|c|c|c|c|c|c|}
\hline \multirow{2}{*}{$\begin{array}{l}\text { CHILDREN } \\
\text { (n) }\end{array}$} & \multicolumn{2}{|c|}{ CARRIERS } & \multicolumn{2}{|c|}{$\begin{array}{c}\text { C. JEJUNI } \\
\text { SSP. JEJUNI }\end{array}$} & \multicolumn{2}{|c|}{ C.COLI } & \multicolumn{2}{|c|}{ C. LARI } & \multicolumn{2}{|c|}{$\begin{array}{c}\text { C. JEJUNI } \\
\text { SSP. DOYLEI }\end{array}$} & \multicolumn{2}{|c|}{$\begin{array}{c}\text { C. } \\
\text { UPSALIENSIS }\end{array}$} & \multicolumn{2}{|c|}{$\begin{array}{l}\text { C. FETUS } \\
\text { SPP. FETUS }\end{array}$} \\
\hline & $\mathrm{N}^{\circ}$ & $\%$ & $\mathrm{~N}^{\circ}$ & $\%$ & $\mathrm{~N}^{\circ}$ & $\%$ & $\mathrm{~N}^{\circ}$ & $\%$ & $\mathrm{~N}^{\circ}$ & $\%$ & $\mathrm{~N}^{\mathrm{o}}$ & $\%$ & $\mathrm{~N}^{\mathrm{o}}$ & $\%$ \\
\hline WELL-NOURISHED & 11 & $9.9 *$ & 5 & 4.5 & 1 & 0.9 & 0 & 0.0 & 2 & 1.8 & 3 & 2.7 & 0 & $0.0^{*}$ \\
\hline MALNOURIS & 33 & $31.4 *$ & 5 & 4.8 & 3 & 2.9 & 8 & $7.6^{*}$ & 1 & 0.9 & 14 & $13.3^{*}$ & 2 & $1.9^{*}$ \\
\hline TOTAL (216) & 44 & 20.4 & 10 & 4.6 & 4 & 1.9 & 8 & 3.7 & 3 & 1.4 & 17 & 7.9 & 2 & 0.9 \\
\hline
\end{tabular}

$* \mathrm{p}<0.05$.

upsaliensis was the most frequent (13.3\%) species isolated from malnourished children, followed by C. lari (7.6\%) and C. fetus ssp. fetus (1.9\%). These last two species were isolated only from malnourished children.

The higher frequency of isolation and the presence of more Campylobacter species among malnourished children could be related to an impaired immunological condition. Malnutrition can predispose to infection by negatively impacting the protection barrier of the intestinal mucous membrane and by inducing changes in host immune functions (1). Malnourished infected children from developing countries have shown higher fractions of Ddull lymphocytes and lower fractions of memory lymphocytes than well-nourished infected children. Impairment of the transformation of the Ddull cells in memory cells in malnourished children may explain these findings and may be one of the mechanisms involved in immunodeficiency in these children (17). Whether or not this immunological condition promotes the establishment of carrier states and the wide spectrum of Campylobacter species isolated among malnourished children deserves further studies.

C. jejuni subsp. jejuni isolation rate was similar to those found in some Latin American countries (5). It has also been demonstrated that malnourished children from developing countries may be more predisposed to gastrointestinal infections with $C$. jejuni subsp. jejuni $(10,14)$. This fact, added to the immunodeficiency and intestinal mucosal compromise secondary to malnutrition (4) could represent, for this kind of children, an increased risk of $C$. jejuni subsp. jejuni bacteremia and Guillain-Barré syndrome (9).

C. jejuni subsp. doyle $i$ was isolated only with the filtration technique from both well-nourished and malnourished children. C. jejuni subsp. doylei is susceptible to cephalothin, present in Skirrow agar plates, and does not grow at $42^{\circ} \mathrm{C}$, all of which may explain these results (8). Previously, we reported the isolation of this microorganism from a child suffering acute diarrhea by using the same passive filtration methodology (8).

C. lari and C. fetus subsp. fetus were isolated only from malnourished children. Although C. lari was firstly isolated from an asymptomatic 6-year-old boy, it is recognized as an enteropathogen for both immunocompetent and immunocompromised persons. In our study, C. lari was the second most isolated species (7.6\%) among malnourished children. These results are surprising because $C$. lari seems to be infrequently isolated from diarrheal cases (11). C. fetus subsp. fetus is a zoonotic opportunistic microorganism mostly associated with blood infections. It could also be an agent of diarrheal disease in humans. However, C. fetus subsp. fetus seems to be rarely isolated from pediatric patients with diarrhea (11).

C. upsaliensis is a recognized enteropathogen for both normal and immunocompromised individuals. In this study, it was isolated from both wel-nourished and malnourished children. However, their isolation rate was significantly higher in the last group $(\mathrm{p}<0.05)$. C. upsaliensis has been previously isolated in our region using exclusively the filtration method (7) because its natural sensitivity to cephalothin and other antimicrobials included in selective media.

It is possible that the poor nutritional status of malnourished children could be a risk factor for harboring exclusively $C$. lari and $C$. fetus subsp. fetus, and for a higher isolation rate of $C$. upsaliensis. The influence of a poor nutritional status as a risk factor for the carriage of Campylobacter species must still be determined.

Understanding the prevalence of different pathogens in communities with special characteristics is necessary to explain their ecological distribution and source of transmission. The fact that among both groups of children, species collectively designed as non-jejuni non-coli were found, led us to infer that those species could also be involved in diarrheal processes, being misdiagnosed when solely the traditional selective media for Campylobacter and $42^{\circ}$ incubation temperature are used. Due to their biological characteristics, antimicrobial susceptibility and temperature growth requirements, several Campylobacter species, such as $C$. upsaliensis, $C$. jejuni subsp. doylei and $C$. fetus subsp. fetus, could be under-reported in clinical specimens. To avoid the misdiagnosis of Campylobacter species that could be involved in infectious processes, it is necessary to use, in addition to traditional selective methods, the filtration protocol as described by Le Roux and Lastovica (12) and Fernández et al. $(7,8)$. This method could improve routine diagnosis, surveillance and epidemiologic studies, and 
could result in better information about the prevalence, distribution and infectious processes associated with these under-reported Campylobacter species.

\section{ACKNOWLEDGMENTS}

This work was supported by Grant DID-UACH S-2007-37.

\section{RESUMO}

\section{Ocorrência de espécies de Campylobacter em crianças malnutridas e bem nutridas}

A ocorrência de espécies de Campylobacter em crianças mal nutridas e bem nutridas, sem diarréia e de baixo nível socioeconômico, foi determinada. Os portadores de Campylobacter foram mais freqüentes entre as crianças mal nutridas $(31,4 \%)$ do que entre as crianças bem nutridas $(9,9 \%)$. Seis espécies de Campylobacter foram isoladas das crianças mal nutridas e quatro das crianças bem nutridas. $C$. upsaliensis foi a espécie mias freqüentemente isolada $(13,3 \%)$ das crianças mal nutridas, seguida de $C$. lari $(7,6 \%)$ e $C$. fetus ssp.fetus $(1,9 \%)$.

Palavras-chave: Espécies de Campylobacter, crianças mal nutridas, crianças bem nutridas, portadores.

\section{REFERENCES}

1. Brown, K.H. (2003). Diarrhea and malnutrition. J. Nutr., 133, 328S332S.

2. Coker, A.O.; Isokpehi, R.D.; Thomas, B.N.; Amisu, K.O.; Obi, C.L. (2002). Human campylobacteriosis in developing countries. Emerg. Infect. Dis., 8, 237-243.

3. De Mol, P.; Brasseur, D.; Hemelhof, B.; Kalala, T.; Butzler, J.P.; Vis, H. L. (1983). Enteropathogenic agents in children with diarrhea in rural Zaire. The Lancet, 1, 516-518.

4. Fagundes Neto, U.; Scaletzky, I. (2000). Escherichia coli infections and malnutrition. The Lancet Perspectives, 27, 356.

5. Fernández, H. (1992). Thermotolerant Campylobacter species associated with human diarrhea in Latin America. J. Braz. Ass. Adv. Sci., 44, 39-43.

6. Fernández, H.; Kahler, K.; Salazar, R.; Ríos, M. (1994). Prevalence of thermotolerant species of Campylobacter and their biotypes in children and domestic birds and dogs in Southern Chile. Rev. Inst. Med. Trop., 36, 433-436.

7. Fernández, H.; Merino, R.; Riquelme, A.; Navarrete, M.; Lincopán, N.; Vandamme, P. (1998). C. upsaliensis: first clinical report and identification of a reservoir in Chile. Rev. Méd. Chile, 126, 343344.

8. Fernández, H.; Rodríguez, R.; Barudi, C.; Lobos, M. (2002). A case of acute diarrhea due to the emerging pathogen Campylobacter jejuni subsp. doylei in southern Chile. Braz. J. Microbiol., 33, 1-3.

9. Gadewar, S.; Fasano, A. (2005). Current concepts in the evaluation, diagnosis and management of acute infectious diarrhea. Curr. Opin. Pharmacol., 5, 559-565.

10. Kakai, R.; Wamola, I.A.; Bwayo, J.J.; Ndinya-Achola, J.O. (1995). Enteric pathogens in malnourished children with diarrhoea. East. Afr. Med. J., 72, 288-289.

11. Lastovica, A.J.; Skirrow, M.B. (2000.) Clinical significance of Campylobacter and related species other than Campylobacter jejuni and C. coli. In: Nachamkin, I.; Blaser, M.J. (eds.). Campylobacter $2^{\text {nd }}$ Edition. ASM Press. Washington, DC, USA. p.89-120.

12. Le Roux, E.; Lastivica, A. (1998.) The Cape Town Protocol: how to isolate the most campylobacters for your dollar, pound, franc, yen, etc. In: Lastovica, A.J.; Newel, D.J.; Lastovica, E.E. (eds.). Campylobacter, Helicobacter and Related Organisms. Institute of Child Health. Cape Town. South Africa. p.30-33.

13. Lima, A.A.M.; Moore, S.R.; Barboza, M.S. Jr.; Soares, A.M.; Scleupner, M.A.; Newman, R.D.; Sears, C.L.; Nataro, J.P.; Fedorko, J.P.; Wuhib, T.; Schorling, J.B.; Guerrant, R.L. (2000). Persistent diarrhea signals a critical period of increased diarrhea burdens and nutritional shortfalls: a perspective cohort study among children in northeastern Brazil. $J$. Infect. Dis., 181, 1643-1651.

14. Lloyd-Evans, N.; Drasar, B.S.; Tomkins, A.M. (1983). A comparison of the prevalence of Campylobacter, Shigellae and Salmonellae in faeces of malnourished and well nourished children in The Gambia and Northern Nigeria. Trans. R. Soc. Trop. Med. Hyg., 77, 245-247.

15. Mathan, V.I.; Rajan, D.P. (1986). The prevalence of bacterial intestinal pathogens in healthy rural population in southern India. $J$. Med. Microbiol., 22, 93-96,

16. Nachamkin, I. (2001). Campylobacter enteritis and the GuillainBarré Syndrome. Curr. Infect. Dis. Rep., 3, 116-122.

17. Nájera, O.; González, C.; Toledo, G.; López, L.; Cortés, E.; Betancourt, M.; Ortiz, R. (2001). CD45RA and CD45RO isoforms in infected malnourished and infected well-nourished children. Clin. Exp. Immunol., 126, 461-465.

18. Sepulveda, J.; Willett, W.; Munoz, A. (1988). Malnutrition and diarrhea. A longitudinal study among urban Mexican children. Am. J. Epidemiol., 127, 365-376.

19. Vandamme, P.; Dewhirst, F.E.; Paster, B.J.; On, S.L.W. (2005). Genus I. Campylobacer. In: Garrity, G.M. (ed). Bergey's Manual of Systematic Bacteriology. 2nd edition, Volume 2, Springer, New York, USA. p.1147-1160. 